\title{
Long-term effects of oral tea polyphenols and Lactobacillus brevis M8 on biochemical parameters, digestive enzymes, and cytokines expression in broilers
}

\author{
Hua-li LI ${ }^{1}$, Zong-jun $\mathrm{LI}^{\dagger 1,2}$, Zhong-shan $\mathrm{WEI}^{3}$, Ting LIU ${ }^{1}$, Xiao-zuo ZOU ${ }^{1}$, Yong LIAO ${ }^{1}$, Yu LUO ${ }^{3}$ \\ ( ${ }^{1}$ Hunan Provincial Key Laboratory of Food Science and Biotechnology, College of Food Science and Technology, \\ Hunan Agricultural University, Changsha 410128, China) \\ $\left({ }^{2}\right.$ National Research Center of Engineering Technology for Utilization of Functional Ingredients from Botanicals, Changsha 410128, China) \\ ( ${ }^{3}$ Hunan Institute of Animal and Veterinary Science, Changsha 410131, China) \\ †E-mail: hnlizongjun@163.com \\ Received June 28, 2015; Revision accepted Sept. 14, 2015; Crosschecked Nov. 18, 2015
}

\begin{abstract}
This study investigates the long-term effects of oral tea polyphenols (TPs) and Lactobacillus brevis M8 (LB) on biochemical parameters, digestive enzymes, and cytokines expression in broilers. In experiment 1, 240 broiler chickens were selected to investigate the effects of $0.06 \mathrm{~g} / \mathrm{kg}$ body weight (BW) TP and $1.0 \mathrm{ml} / \mathrm{kg} \mathrm{BW}$ LB on broilers; in experiment 2, 180 broiler chickens were assigned randomly to three groups to investigate the effects of different dosages of TP $(0.03,0.06$, and $0.09 \mathrm{~g} / \mathrm{kg} \mathrm{BW})$ combined with $1.0 \mathrm{ml} / \mathrm{kg} \mathrm{BW} \mathrm{LB}$ on broilers; in experiment 3,180 broiler chickens were assigned randomly to three groups to investigate the effects of different dosages of LB $(0.5,1.0$, and $1.5 \mathrm{ml} / \mathrm{kg} \mathrm{BW}$ ) combined with $0.06 \mathrm{~g} / \mathrm{kg}$ BW TP on broilers. The results showed that TP and LB affected serum biochemical parameters, and TP reduced serum cholesterol $(\mathrm{CHO})$ and low-density lipoprotein cholesterol (LDL-C) abundances in a dosage-dependent manner $(P<0.05)$ on Day 84. Meanwhile, broilers fed a diet supplemented with TP or LB had a lower intestinal lipase activity on Day 84 compared with the control group $(P<0.05)$. Middle and high dosages of TP increased pancreatic lipase and proventriculus pepsin activities $(P<0.05)$. Also middle and high dosages of LB significantly enhanced pancreatic lipase activity $(P<0.05)$, while high LB supplementation inhibited intestinal trypsase $(P<0.05)$ on Day 84. Furthermore, both TP and LB reduced intestinal cytokine expression and nuclear factor-K B (NF-KB) mRNA level on Days 56 and 84. In conclusion, long-term treatment of TP and LB improved lipid metabolism and digestive enzymes activities, and affected intestinal inflammatory status, which may be associated with the NF-KB signal.
\end{abstract}

Key words: Tea polyphenols, Lactobacillus brevis, Cytokines, Broilers doi: 10.1631 jzus.B1500160

Document code: A

CLC number: S831.5

\section{Introduction}

Previous studies have examined the bioavailability of tea polyphenols (TPs) and indicated that the possible mechanism for the beneficial effects of TP include vasculoprotective, anti-oxidative, anti-

\footnotetext{
¿ Corresponding author

(D) ORCID: Hua-li LI, http://orcid.org/0000-0003-2210-2780

(C) Zhejiang University and Springer-Verlag Berlin Heidelberg 2015
}

thrombogenic, anti-inflammatory, and lipid-lowering properties (Kanwar et al., 2012; Murakami, 2014; Chen and Lin, 2015). Shen et al. (2011a) reported that dietary TP attenuates lipopolysaccharide-induced myocardial fibrosis through a suppression of chronic inflammation and innate immune responses in rats. In chickens, TP supplementation has been demonstrated to alleviate obesity through the regulation of lipidmetabolism-related genes and transcription factor expression (Huang et al., 2013) and reduce glucocorticoid- 
induced growth inhibition and oxidative stress in broiler chickens (Eid et al., 2003).

Lactic acid bacteria (LAB) are comprised of an ecologically diverse group of microorganisms united by formation of lactic acid as the primary metabolite of sugar metabolism. Currently, LAB have been considered to be the most common type of microbes used as probiotics and have been successfully used in improving intestinal microflora, prevention of infectious diseases and food allergies, reduction of serum cholesterol (CHO), anticarcinogenic activity, stabilization of the gut mucosal barrier, immune adjuvant properties, alleviation of intestinal bowel disease symptoms, and improvement in the digestion of lactose in intolerant hosts (Kumari et al., 2011; Berlec et al., 2012; Zhong et al., 2014; Rashti et al., 2015). Meanwhile, LAB have been suggested as improving growth performance and production in swine (Yang et al., 2015) and broilers (Chen et al., 2012). Our previous studies suggested that co-dietary TP and LAB supplementation improve growth performance and intestinal microflora in chickens, while little is known about the long-term effects of co-dietary TP and $\mathrm{LAB}$ supplementation in birds. Thus, the current study was to investigate the effects of TP and LAB on lipid-metabolic parameters, digestive enzymes, and cytokines expression in chickens.

\section{Materials and methods}

\subsection{Chicks, diets, and experimental design}

One-day-old yellow-feathered broiler chickens were obtained from the Hunan Animal Husbandry and Veterinary Research Institute (Changsha, China). The animal care protocol was approved by the Hunan Agricultural University Animal Care and Use Committee (Changsha, China). Birds were housed in an electrically heated thermostatically controlled room with feeders, nipple drinkers, and steel cages. Feed and tap water were available ad libitum. All birds were offered the same basal diet, which was formulated to meet or slightly exceed the NRC (1994) broilers requirements for all nutrients.

Experiment 1: 240 broiler chickens were assigned randomly to four groups: one control group (Control), one TP group (TP) in which birds were administered $0.06 \mathrm{~g} / \mathrm{kg}$ body weight (BW) TP by oral gavage, one Lactobacillus brevis M8 (LB) group (LB) in which birds were administered $1.0 \mathrm{ml} / \mathrm{kg} \mathrm{BW}$ LB by oral gavage, and a combined group (TPLB) in which birds orally received $0.06 \mathrm{~g} / \mathrm{kg} \mathrm{BW} \mathrm{TP}$ and $1.0 \mathrm{ml} / \mathrm{kg} \mathrm{BW}$ LB. Each group comprised 6 replicate cages with 10 birds per cage in a completely randomized design. LB, after being grown in de ManRogosa-Sharpe (MRS) liquid medium (Difco, USA), was adjusted to $2.15 \times 10^{8} \mathrm{CFU} / \mathrm{ml}$ and stored at $-80^{\circ} \mathrm{C}$ prior to feeding. TP was purchased from Xi' an Xuhuang Bio-Tech Co., Ltd. (Xi'an, China), with a purity higher than $98 \%$. Every $1000 \mathrm{mg}$ TP contained $69.8 \mathrm{mg}$ caffeine, $495 \mathrm{mg}(-)$-epigallocatechin gallate, $112 \mathrm{mg}(-)$-epicatechin gallate, $100 \mathrm{mg}(-)$-epicatechin, $78 \mathrm{mg}(-)$-epigallocatechin, and $96 \mathrm{mg}(-)$-gallocatechin gallate according to high-performance liquid chromatography-ultraviolet (HPLC-UV) analysis.

Experiment 2: 180 broiler chickens were assigned randomly to three groups, with 6 replicate cages with 10 birds per cage in a completely randomized design. All birds received $1.0 \mathrm{ml} / \mathrm{kg} \mathrm{BW} \mathrm{LB}$ combined with 0.03 (LTP), 0.06 (MTP), and 0.09 (HTP) $\mathrm{g} / \mathrm{kg}$ BW TP.

Experiment 3: 180 broiler chickens were assigned randomly to three groups, with 6 replicate cages with 10 birds per cage in a completely randomized design. All birds received $0.06 \mathrm{~g} / \mathrm{kg} \mathrm{BW}$ TP combined with 0.5 (LLB), 1.0 (MLB), and 1.5 (HLB) $\mathrm{ml} / \mathrm{kg} \mathrm{BW}$ LB.

On Days 56 and 84, five birds from each replicate cage were slaughtered. Blood, glandular stomach, pancreas, and middle section of ileum were collected for further analyses (Guan et al., 2013).

\subsection{Determination of serum biochemical parameters}

Blood was centrifuged at $3000 \mathrm{r} / \mathrm{min}$ for $10 \mathrm{~min}$. Serum was separated into Eppendorf tubes, and stored at $-80{ }^{\circ} \mathrm{C}$ for further analyses. Assay kits for the analysis of serum biochemical parameters were obtained from Nanjing Jiancheng Biotechnology Institute, China. Serum fasting blood glucose (GLU), low-density lipoprotein cholesterol (LDL-C), total glycerin trilaurate (TG), $\mathrm{CHO}$, and high-density lipoprotein cholesterol (HDL-C) were determined using an Automatic Biochemistry Radiometer (Au640, Olympus). 


\subsection{Determination of digestive enzymes}

Glandular stomach, pancreas, and middle intestine samples were collected for analyzing intestinal amylase, pancreatic amylase, intestinal lipase, pancreatic lipase, proventriculus pepsin, intestinal trypsase and pancreatic trypsase using spectrophotometric kits in accordance with the manufacturer's instructions (Nanjing Jiancheng Biotechnology Institute, China).

\subsection{Complementary DNA (cDNA) synthesis and mRNA quantification by real-time polymerase chain reaction $(\mathrm{PCR})$ analysis}

Extraction of total RNA and its reverse transcription were performed according to previous reports (Yin et al., 2013a; 2014a). Primers were designed with Primer 5.0 according to the gene sequence of chicken (http://www.ncbi.nlm.nih.gov/pubmed) to produce an amplification product: IL-1 $\beta$ (forward: 5'-CGA GGA GCA GGG ACT TTG C-3'; reserve: 5'-GAA GGT GAC GGG CTC AAA AA-3'), IL-4 (forward: 5'-GCT CTC AGT GCC GCT GAT G-3'; reserve: 5'-GAA ACC TCT CCC TGG ATG TCA T-3'), IL-6 (forward: 5'-GCT TCG ACG AGG AGA AAT GC-3'; reserve: 5'-GGT AGGTC TGA AAG GCG AAC AG-3'), IL-10 (forward: 5'-CGC TGT CAC CGC TTC TTC A-3'; reserve: 5'-CGT CTC CTT GAT CTG CTT GAT G-3'), TNF- $\alpha$ (forward: 5'-TGT GTA TGT GCA GCA ACC CGT AGT-3'; reserve: 5'-GGC ATT GCA ATT TGG ACA GAA GT-3'), IFN- $\gamma$ (forward: 5'-GTC TTG CTC CTT CAA CGA CA-3'; reserve: 5'-GCG CTG TAA TCG TTG TCT TG-3'), NF-кB (forward: 5'-TTG CTG CTG GAG TTG ATG TC-3'; reserve: 5'-TGC TAT GTG AAG AGG CGT TG-3'), Myd88 (forward: 5'-AGC GTG GAG GAG GAC TGC AAG AAG-3'; reserve: 5'-CCG ATC AAA CAC ACA CAG CTT CAG-3'), and TLR4 (forward: 5'-AGT CTG AAA TTG CTG AGC TCA AAT-3'; reserve: 5'-GCG ACG TTA AGC CAT GGA AG-3'). $\beta$-Actin was used as a house keeping gene to normalize target gene transcript levels (forward: 5'-CAT CCT GCG TCT GGA CCT GG-3'; reserve: 5'-TAA TGT CAC GCA CGA TTT CC-3'). Real-time PCR was performed according to previous studies (Yin et al., 2014b; 2015a). Relative expression was normalized and expressed as a ratio to the expression in the control group.

\subsection{Statistical analysis}

All statistical analyses were performed using SPSS 17.0 software. Data were obtained using the one-way analysis of variance (ANOVA) to test homogeneity of variances via Levene's test followed with Tukey's multiple comparison tests. The results are expressed as the mean \pm standard error of the mean. Values in the same row with different superscripts are significant $(P<0.05)$, while values with the same superscripts are not significantly different $(P>0.05)$.

\section{Results}

\subsection{Effects of TP and LB on serum biochemical parameters in chickens}

The serum biochemical parameters on Day 84 are shown in Table 1. Supplementation with TP or LB significantly decreased serum LDL-C and TG concentrations $(P<0.05)$ compared with the control group. LDL-C in the TPLB group was markedly lower than that in the LB group, and TG in the TPLB group was much lower compared with other groups $(P<0.05)$. Supplementation with TP decreased serum HDL-C concentrations $(P<0.05)$.

In experiment 2, supplementation with middle dosage of TP markedly decreased the serum LDL-C level compared with other groups $(P<0.05)$. TP reduced serum $\mathrm{CHO}$ and HDL-C abundances in a dosagedependent manner $(P<0.05)$. In experiment 3 , high dosage of LB enhanced serum GLU and reduced serum TG compared with the LLB and MLB groups $(P<0.05)$.

\subsection{Effects of TP and LB on digestive enzymes in chickens}

Broilers fed a diet with TP or LB had a lower intestinal lipase activity on Day 84 of age compared with the control group $(P<0.05)$. Pancreatic lipase activities in TP and TPLB groups were significantly higher than those in the control and LB groups $(P<0.05$; Table 2$)$.

Compared with the LTP group, middle and high dosages of TP increased pancreatic lipase and proventriculus pepsin activities $(P<0.05)$. Meanwhile, middle and high dosages of LB significantly enhanced pancreatic lipase activity $(P<0.05)$, while high LB supplementation inhibited intestinal trypsase compared with the LLB and MLB groups $(P<0.05$; Table 2$)$. 
Table 1 Effects of TP and LB on serum biochemical parameters in broilers

\begin{tabular}{lccccc}
\hline Group & LDL-C $(\mathrm{mmol} / \mathrm{L})$ & GLU $(\mathrm{mmol} / \mathrm{L})$ & TG $(\mathrm{mmol} / \mathrm{L})$ & CHO $(\mathrm{mmol} / \mathrm{L})$ & HDL-C $(\mathrm{mmol} / \mathrm{L})$ \\
\hline Experiment 1 & & & & & \\
Control & $1.36 \pm 0.11^{\mathrm{a}}$ & $10.89 \pm 0.61$ & $0.44 \pm 0.04^{\mathrm{a}}$ & $3.43 \pm 0.45$ & $2.13 \pm 0.09^{\mathrm{a}}$ \\
TP & $0.92 \pm 0.02^{\mathrm{bc}}$ & $8.62 \pm 0.24$ & $0.34 \pm 0.05^{\mathrm{b}}$ & $3.18 \pm 0.18$ & $1.86 \pm 0.38^{\mathrm{b}}$ \\
LB & $1.03 \pm 0.13^{\mathrm{b}}$ & $11.32 \pm 0.74$ & $0.26 \pm 0.01^{\mathrm{b}}$ & $2.65 \pm 0.68$ & $2.09 \pm 0.07^{\mathrm{ab}}$ \\
TPLB & $0.88 \pm 0.03^{\mathrm{c}}$ & $12.86 \pm 0.63$ & $0.15 \pm 0.01^{\mathrm{c}}$ & $3.14 \pm 0.23$ & $2.05 \pm 0.05^{\mathrm{ab}}$ \\
Experiment 2 & & & & \\
LTP & $0.51 \pm 0.05^{\mathrm{b}}$ & $11.02 \pm 0.50$ & $0.19 \pm 0.05$ & $3.37 \pm 0.06^{\mathrm{a}}$ & $2.20 \pm 0.04^{\mathrm{a}}$ \\
MTP & $0.88 \pm 0.03^{\mathrm{a}}$ & $12.86 \pm 0.33$ & $0.15 \pm 0.03$ & $3.14 \pm 0.04^{\mathrm{ab}}$ & $2.05 \pm 0.05^{\mathrm{b}}$ \\
HTP & $0.56 \pm 0.03^{\mathrm{b}}$ & $12.89 \pm 0.24$ & $0.14 \pm 0.02$ & $2.82 \pm 0.10^{\mathrm{b}}$ & $2.04 \pm 0.04^{\mathrm{b}}$ \\
Experiment 3 & & & & & \\
LLB & $0.84 \pm 0.09$ & $11.33 \pm 0.43^{\mathrm{b}}$ & $0.40 \pm 0.02^{\mathrm{a}}$ & $3.23 \pm 0.08$ & $2.23 \pm 0.06$ \\
MLB & $0.88 \pm 0.03$ & $12.86 \pm 0.33^{\mathrm{ab}}$ & $0.15 \pm 0.01^{\mathrm{b}}$ & $3.14 \pm 0.04$ & $2.05 \pm 0.05$ \\
HLB & $0.80 \pm 0.07$ & $13.45 \pm 0.78^{\mathrm{a}}$ & $0.12 \pm 0.01^{\mathrm{b}}$ & $3.06 \pm 0.08$ & $2.27 \pm 0.08$ \\
\hline
\end{tabular}

Data are expressed as means \pm standard error of the mean (SEM) $(n=60)$. Values in a row with different superscripts differ significantly $(P<0.05)$

Table 2 Effects of TP and LB on digestive enzymes in broilers

\begin{tabular}{|c|c|c|c|c|c|c|c|}
\hline Group & $\begin{array}{c}\text { Intestinal } \\
\text { amylase } \\
\text { (U/mg prot) } \\
\end{array}$ & $\begin{array}{c}\text { Pancreatic } \\
\text { amylase } \\
\text { (U/mg prot) }\end{array}$ & $\begin{array}{c}\text { Intestinal } \\
\text { lipase } \\
\text { (U/mg prot) } \\
\end{array}$ & $\begin{array}{l}\text { Pancreatic } \\
\text { lipase } \\
\text { (U/mg prot) }\end{array}$ & $\begin{array}{c}\text { Proventriculus } \\
\text { pepsin } \\
\text { (U/mg prot) }\end{array}$ & $\begin{array}{c}\text { Intestinal } \\
\text { trypsase } \\
\text { (U/mg prot) } \\
\end{array}$ & $\begin{array}{c}\text { Pancreatic } \\
\text { trypsase } \\
\text { (U/mg prot) } \\
\end{array}$ \\
\hline \multicolumn{8}{|c|}{ Experiment 1} \\
\hline Control & $0.53 \pm 0.04$ & $0.76 \pm 0.07$ & $177.67 \pm 7.59^{\mathrm{a}}$ & $162.82 \pm 8.76^{\mathrm{b}}$ & $5.82 \pm 0.87^{\mathrm{ab}}$ & $0.20 \pm 0.02$ & $0.20 \pm 0.06^{\mathrm{ab}}$ \\
\hline $\mathrm{TP}$ & $0.45 \pm 0.07$ & $0.71 \pm 0.04$ & $137.39 \pm 5.04^{\mathrm{b}}$ & $215.70 \pm 10.75^{\mathrm{a}}$ & $3.05 \pm 0.08^{\mathrm{b}}$ & $0.22 \pm 0.05$ & $0.27 \pm 0.03^{\mathrm{a}}$ \\
\hline LB & $0.59 \pm 0.08$ & $0.77 \pm 0.02$ & $142.00 \pm 10.13^{\mathrm{b}}$ & $194.53 \pm 3.48^{\mathrm{ab}}$ & $5.28 \pm 0.46^{\mathrm{ab}}$ & $0.21 \pm 0.02$ & $0.16 \pm 0.02^{b}$ \\
\hline TPLB & $0.64 \pm 0.04$ & $0.78 \pm 0.01$ & $144.40 \pm 6.74^{\mathrm{b}}$ & $217.58 \pm 4.15^{\mathrm{a}}$ & $6.39 \pm 0.43^{\mathrm{a}}$ & $0.22 \pm 0.01$ & $0.29 \pm 0.03^{\mathrm{a}}$ \\
\hline \multicolumn{8}{|c|}{ Experiment 2} \\
\hline LTP & $0.60 \pm 0.05$ & $0.77 \pm 0.02$ & $132.24 \pm 6.64$ & $141.70 \pm 4.09^{\mathrm{b}}$ & $5.85 \pm 0.69^{b}$ & $0.22 \pm 0.01$ & $0.28 \pm 0.06$ \\
\hline MTP & $0.64 \pm 0.04$ & $0.78 \pm 0.01$ & $144.40 \pm 6.74$ & $217.58 \pm 4.15^{\mathrm{a}}$ & $6.39 \pm 0.43^{\mathrm{ab}}$ & $0.22 \pm 0.01$ & $0.29 \pm 0.03$ \\
\hline НTP & $0.58 \pm 0.00$ & $0.79 \pm 0.01$ & $149.78 \pm 8.33$ & $230.13 \pm 4.78^{\mathrm{a}}$ & $8.69 \pm 0.45^{\mathrm{a}}$ & $0.22 \pm 0.02$ & $0.22 \pm 0.02$ \\
\hline \multicolumn{8}{|c|}{ Experiment 3} \\
\hline LLB & $0.59 \pm 0.05$ & $0.77 \pm 0.02$ & $157.59 \pm 5.39$ & $163.13 \pm 6.98^{\mathrm{b}}$ & $5.63 \pm 0.64$ & $0.22 \pm 0.02^{\mathrm{a}}$ & $0.22 \pm 0.04$ \\
\hline MLB & $0.64 \pm 0.04$ & $0.78 \pm 0.01$ & $144.40 \pm 6.74$ & $217.58 \pm 4.15^{\mathrm{a}}$ & $6.39 \pm 0.43$ & $0.22 \pm 0.01^{\mathrm{a}}$ & $0.29 \pm 0.03$ \\
\hline HLB & $0.59 \pm 0.05$ & $0.77 \pm 0.01$ & $125.81 \pm 4.07$ & $218.47 \pm 5.15^{\mathrm{a}}$ & $5.94 \pm 0.26$ & $0.16 \pm 0.02^{\mathrm{b}}$ & $0.24 \pm 0.05$ \\
\hline
\end{tabular}

Data are expressed as means $\pm \operatorname{SEM}(n=60)$. Values in a row with different superscripts differ significantly $(P<0.05)$

\subsection{Effects of TP and LB on intestinal gene expression}

On Day 56, supplementation with TP or LB significantly down-regulated IL- $1 \beta$ expression compared with the control group $(P<0.05)$. Coadministration of TP and LB markedly reduced IL-6, IL-10, and TNF- $\alpha$ mRNA abundances $(P<0.05$; Fig. 1a). Co-administration of TP and LB changed intestinal TLR4 and NF- $\mathrm{KB}$ expression $(P<0.05$; Fig. 1b). On Day 84, broilers in the TPLB group exhibited lower abundances of IL-1 $\beta$, IL-6, TNF- $\alpha$, and NF-kB mRNA $(P<0.05$; Fig. 1$)$ compared with the control group.
In experiment 2, different dosages of TP affected intestinal IL-1 $\beta$, IL-4, IL-10, and NF-kB expression $(P<0.05)$ on Day 56 (Fig. 2a) and influenced IL-1 $\beta$, IFN- $\gamma$, and NF- $\mathrm{kB}$ expression $(P<0.05)$ on Day 84 (Fig. 2b) in chickens. In experiment 3, administration of a high dosage of LB markedly inhibited IL- 6 and IL-10 expression and enhanced TLR4 mRNA abundance $(P<0.05)$ on Day 56 (Fig. 2c). High dosage of LB down-regulated IL-1 $\beta$ and TNF- $\alpha$ expression $(P<0.05)$ on Day 84 (Fig. 2d). Compared with the LLB and HLB groups, NF- $\mathrm{kB}$ mRNA abundance was significantly lower in the MLB group $(P<0.05$; Fig. 2d). 
(a)

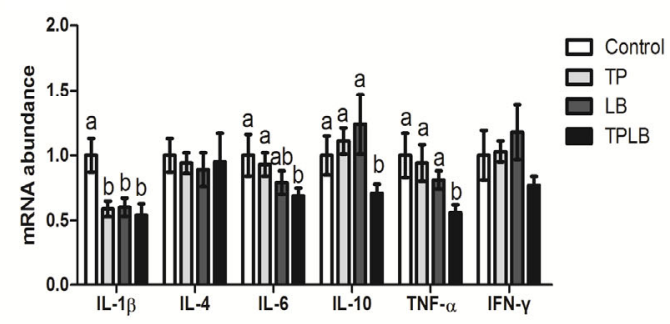

(c)

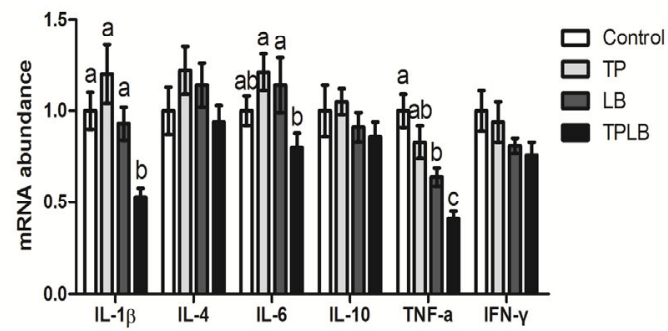

(b)

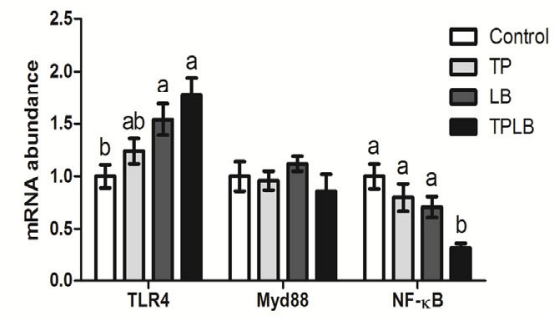

(d)

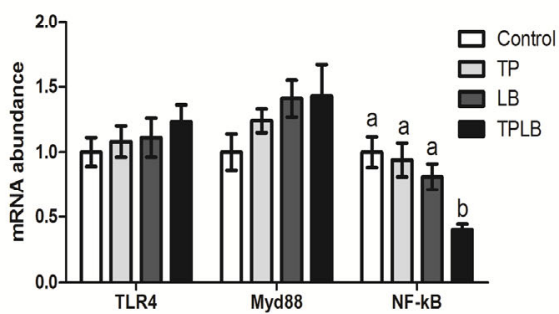

Fig. 1 Effects of TP and LB on expression of genes related to cytokines and NF-кB in broilers in experiment 1 (a) and (b): on Day 56 of age; (c) and (d): on Day 84 of age. The mRNA levels of target genes were normalized using $\beta$-actin. Data are expressed as mean $\pm \operatorname{SEM}(n=60)$. Values with different superscripts differ significantly $(P<0.05)$

(a)

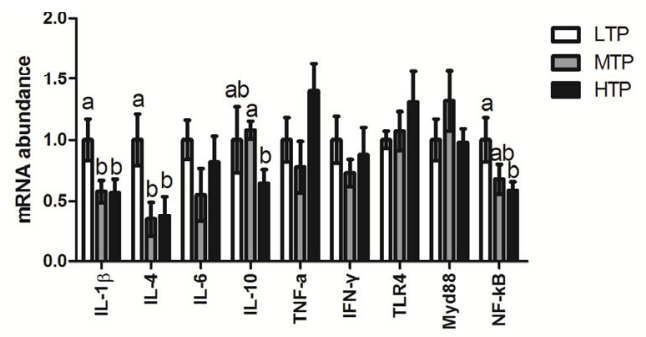

(c)

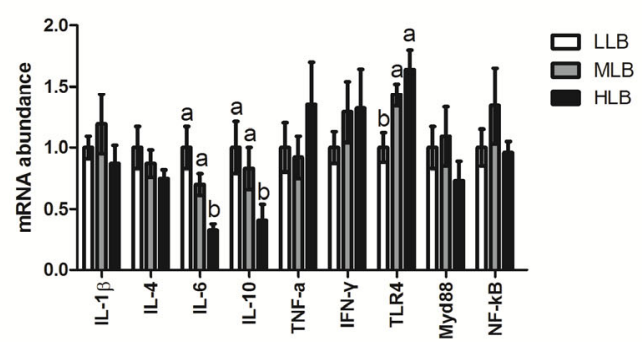

(b)

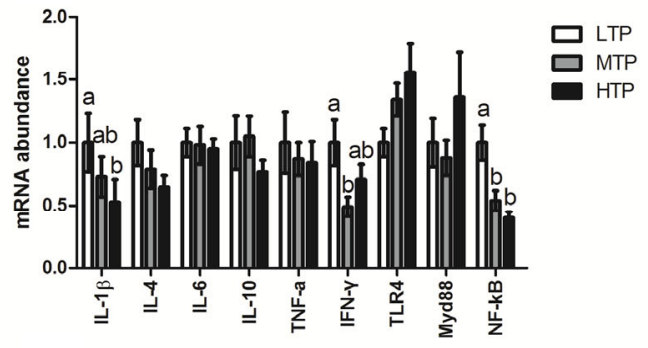

(d)

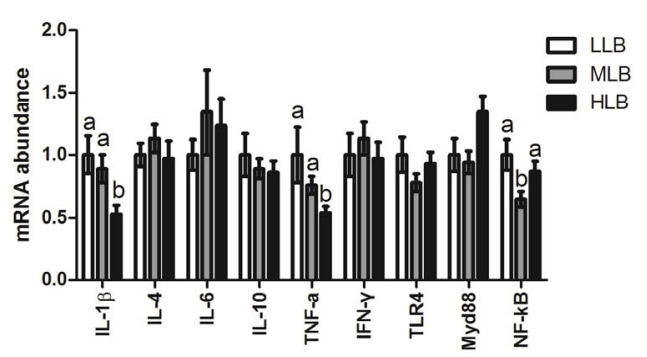

Fig. 2 Effects of TP and LB on expression of genes related to cytokines and NF-KB in broilers in experiments 2 and 3 (a) and (b): experiment 2; (c) and (d): experiment 3. (a) and (c): on Day 56 of age; (b) and (d): on Day 84 of age. The mRNA levels of target genes were normalized using $\beta$-actin. Data are expressed as mean $\pm \operatorname{SEM}(n=60)$. Values with different superscripts differ significantly $(P<0.05)$

\section{Discussion}

Serum levels of GLU, LDL-C, TG, CHO, and HDL-C were tested as a reflection of the metabolism and inner organ status of the animal (Wu et al., 2013). The present study revealed that supplementations with TP and LB influence serum LDL-C, TG, and HDL-C concentrations in chickens. TP reduced serum $\mathrm{CHO}$ and HDL-C abundances in a dosagedependent manner in the presence of LB, while LB affected serum GLU and TG levels. Bornhoeft et al. (2012) reported that dietary $0.2 \%$ TP improved lipid 
metabolism in rats fed an atherogenic diet via mediating serum LDL-C and HDL-C concentrations. The mechanism may be that TP can regulate fatty acid synthesis and lipolysis-related genes, including carnitine palmitoyl transferase I, acyl-CoA oxidase 1, peroxisome proliferator-activated receptor- $\alpha(\operatorname{PPAR} \alpha)$, adipose triglyceride lipase, and lipoprotein lipase (LPL) (Huang et al., 2013; Choi et al., 2015).

$\mathrm{LAB}$ also have been demonstrated to affect the health of the host by modifying fatty acid composition (Kishino et al., 2013). Ito et al. (2015) further investigated the role of $\mathrm{LAB}$ on lipid metabolism and found that $\mathrm{LAB}$ exhibited an anti-oxidative activity against LDL oxidation in vitro. Thus, long-term TP and LB treatment may improve lipid metabolism in chickens.

Digestive enzymes are considered to be reliable indicators of the nutritional condition of the individuals due to their species and age specificity, sensitivity, and short latency (Lazo et al., 2007; Eastep et al., 2015; Hirai et al., 2015). Various factors can influence digestive enzyme activity, including different dietary supplements (Charron et al., 2014). Kusano et al. (2008) reported that TP exhibited lipase and amylase inhibitory activities. The present study also found that oral administration of TP with or without LB inhibited intestinal lipase activity. However, dietary TP in experiment 1 and middle or high dosage of $\mathrm{TP}$ in experiment 2 significantly enhanced pancreatic lipase activity. The reason may be our long-term treatment and the in vivo study. LAB have been widely reported to interact with food matrix components and to be involved in nutrient metabolism and absorption (Burgain et al., 2014; Michlmayr and Kneifel, 2014), while little is known about the effect of LAB on digestive enzymes. Thus, this is the first study to report the inhibitory effect of LAB on intestinal lipase activity. Combined with TP, high dosage of $\mathrm{LAB}$ increased pancreatic lipase activity and reduced intestinal trypsase in this study.

Our previous data revealed that $\mathrm{TP}$ and $\mathrm{LAB}$ improve immune function in chickens (Liu et al., 2014), so we further investigated the effects of TP and LAB on cytokines expression. We found that administration of TP and LAB mediated cytokines expression (IL-1 $\beta$, IL-6, IL-10, TNF- $\alpha$, IFN- $\gamma$ ) on Days 56 and 84. Cytokines play an important role in immune system and inflammatory response (Postal and Appenzeller, 2015). Shen et al. (2011b) reported that green TP reversed LPS-induced chronic inflammation via suppression of TNF- $\alpha$ generation; Qin et al. (2010) also found that supplementation with TP $(200 \mathrm{mg} / \mathrm{kg}$ BW daily) for 6 weeks decreased TNF- $\alpha$, IL- $1 \beta$, and IL-6 mRNA abundances and enhanced the antiinflammatory protein expression in insulin-resistant rats. $\mathrm{LAB}$ have also been reported to regulate proinflammatory cytokines expression (i.e. IL-1 $\beta$, IL-6, IL-10, TNF- $\alpha$, and IFN- $\gamma$ ) and reduce inflammation in animals, including broiler chicks (Chen et al., 2012; Park et al., 2014).

The nuclear factor- $\kappa \mathrm{B}(\mathrm{NF}-\mathrm{\kappa B})$ is involved in cellular response to stimuli such as cytokines, ultraviolet irradiation, oxidized LDL, and microbes or viral antigens. After activation, NF- $\mathrm{kB}$ mediates cell growth, differentiation, development, apoptosis, and oxidative stress (Yin et al., 2013b). Previous reports indicated that LAB (i.e. Lactobacillus plantarum 10hk2 and L. johnsonii HY7042) suppressed proinflammatory cytokine production via inhibiting NF- $\kappa B$ activation (Chon et al., 2010; Joo et al., 2011), which is consistent with the present result that LB down-regulated NF- $\kappa B$ expression. We also found that TP decreased intestinal NF- $\kappa B$ mRNA abundance on Days 56 and 84, which might mediate cytokines expression. Li et al. (2014) reported that TP pretreatment could suppress the TLR4/NF- $\mathrm{KB}$ signaling pathway, protecting renal tubular epithelial cells against ischemia/reperfusion-induced apoptosis and inflammation. The mechanism may be that TP blocked phosphorylation and subsequent degradation of inhibitor of $\kappa \mathrm{B}-\alpha$ and $\kappa \mathrm{B}-\beta$ subunits (Singh et al., 2011), which contributes to NF- $\kappa B$ activation (Yin et al., 2015b).

In conclusion, results from the current study indicated that long-term treatments of TP and LB improved lipid metabolism, activity of digestive enzymes, and intestinal inflammatory status, which might be associated with the NF- $\mathrm{kB}$ signal.

\section{Compliance with ethics guidelines}

Hua-li LI, Zong-jun LI, Zhong-shan WEI, Ting LIU, Xiao-zuo ZOU, Yong LIAO, and Yu LUO declare that they have no conflict of interest.

All experimental protocols were approved by the Ethical Committee for Animal Studies of Hunan Agricultural University Animal Care and Use Committee (Changsha, China). All institutional and national guidelines for the care and use of laboratory animals were followed. 


\section{References}

Berlec, A., Ravnikar, M., Strukelj, B., 2012. Lactic acid bacteria as oral delivery systems for biomolecules. Pharmazie, 67(11):891-898. [doi:10.1691/Ph.2012.1705]

Bornhoeft, J., Castaneda, D., Nemoseck, T., et al., 2012. The protective effects of green tea polyphenols: lipid profile, inflammation, and antioxidant capacity in rats fed an atherogenic diet and dextran sodium sulfate. J. Med. Food, 15(8):726-732. [doi:10.1089/jmf.2011.0258]

Burgain, J., Scher, J., Francius, G., et al., 2014. Lactic acid bacteria in dairy food: surface characterization and interactions with food matrix components. Adv. Colloid Interf. Sci., 213:21-35. [doi:10.1016/j.cis.2014.09.005]

Charron, L., Geffard, O., Chaumot, A., et al., 2014. Influence of molting and starvation on digestive enzyme activities and energy storage in Gammarus fossarum. PLoS ONE, 9(4):e96393. [doi:10.1371/journal.pone.0096393]

Chen, C.Y., Tsen, H.Y., Lin, C.L., et al., 2012. Oral administration of a combination of select lactic acid bacteria strains to reduce the Salmonella invasion and inflammation of broiler chicks. Poult. Sci., 91(9):21392147. [doi:10.3382/ps.2012-02237]

Chen, Z.M., Lin, Z., 2015. Tea and human health: biomedical functions of tea active components and current issues. $J$. Zhejiang Univ.-Sci. B (Biomed. \& Biotechnol.), 16(2): 87-102. [doi:10.1631/jzus.B1500001]

Choi, A.J., Buisson, N., Kim, H.T., 2015. Digestion characteristics and kinetic analysis of bio-molecules in a simulated human intestinal system. Integr. Food Nutr. Metab., 2(3):189-192. [doi:10.15761/IFNM.1000128]

Chon, H., Choi, B., Jeong, G., et al., 2010. Suppression of proinflammatory cytokine production by specific metabolites of Lactobacillus plantarum $10 \mathrm{hk} 2$ via inhibiting NF- $\mathrm{BB}$ and p38 MAPK expressions. Comp. Immunol. Microbiol. Infect. Dis., 33(6):e41-e49. [doi:10. 1016/j.cimid.2009.11.002]

Eastep, J., Chen, G.X., 2015. The relationships of high-fat diet and metabolism of lipophilic vitamins. Integr. Food Nutr. Metab., 2(3):174-179. [doi:10.15761/IFNM.1000125]

Eid, Y.Z., Ohtsuka, A., Hayashi, K., 2003. Tea polyphenols reduce glucocorticoid-induced growth inhibition and oxidative stress in broiler chickens. Br. Poult. Sci., 44(1): 127-132. [doi:10.1080/0007166031000085427]

Guan, R.F., Lyu, F., Chen, X.Q., et al., 2013. Meat quality traits of four Chinese indigenous chicken breeds and one commercial broiler stock. J. Zhejiang Univ.-Sci. B (Biomed. \& Biotechnol.), 14(10):896-902. [doi:10.1631/ jzus.B1300163]

Hirai, F., Matsui, T., 2015. Status of food intake and elemental nutrition in patients with Crohn's disease. Integr. Food Nutr. Metab., 2(2):148-150. [doi:10.15761/IFNM.1000118]

Huang, J.B., Zhang, Y., Zhou, Y.B., et al., 2013. Green tea polyphenols alleviate obesity in broiler chickens through the regulation of lipid-metabolism-related genes and transcription factor expression. J. Agric. Food Chem., 61(36):8565-8572. [doi:10.1021/jf402004x]
Ito, M., Oishi, K., Yoshida, Y., et al., 2015. Effects of lactic acid bacteria on low-density lipoprotein susceptibility to oxidation and aortic fatty lesion formation in hyperlipidemic hamsters. Benef. Microbes, 6(3):287-293. [doi:10.3920/ BM2014.0040]

Joo, H.M., Hyun, Y.J., Myoung, K.S., et al., 2011. Lactobacillus johnsonii HY7042 ameliorates Gardnerella vaginalis-induced vaginosis by killing Gardnerella vaginalis and inhibiting $\mathrm{NF}-\mathrm{\kappa B}$ activation. Int. Immunopharmacol., 11(11):1758-1765. [doi:10.1016/j. intimp.2011.07.002]

Kanwar, J., Taskeen, M., Mohammad, I., et al., 2012. Recent advances on tea polyphenols. Front. Biosci. (Elite Ed.), 4:111-131. [doi:10.2741/E363]

Kishino, S., Takeuchi, M., Park, S.B., et al., 2013. Polyunsaturated fatty acid saturation by gut lactic acid bacteria affecting host lipid composition. PNAS, 110(44):17808-17813. [doi:10.1073/pnas.1312937110]

Kumari, A., Catanzaro, R., Marotta, F., 2011. Clinical importance of lactic acid bacteria: a short review. Acta Biomed., 82(3):177-180.

Kusano, R., Andou, H., Fujieda, M., et al., 2008. Polymer-like polyphenols of black tea and their lipase and amylase inhibitory activities. Chem. Pharm. Bull., 56(3):266-272. [doi:10.1248/cpb.56.266]

Lazo, J.P., Mendoza, R., Holt, G.J., et al., 2007. Characterization of digestive enzymes during larval development of red drum (Sciaenops ocellatus). Aquaculture, 265(1-4): 194-205. [doi:10.1016/j.aquaculture.2007.01.043]

Li, Y.W., Zhang, Y., Zhang, L., et al., 2014. Protective effect of tea polyphenols on renal ischemia/reperfusion injury via suppressing the activation of TLR4/NF- $\mathrm{KB}$ p 65 signal pathway. Gene, 542(1):46-51. [doi:10.1016/j.gene.2014. 03.021]

Liu, T., Li, Z.J., Liao, Y., et al., 2014. Effects of Lactobacillus and tea polyphenols on digestive enzyme activity in broilers. Chin. J. Anim. Sci., 50(3):78-82 (in Chinese).

Michlmayr, H., Kneifel, W., 2014. $\beta$-Glucosidase activities of lactic acid bacteria: mechanisms, impact on fermented food and human health. FEMS Microbiol. Lett., 352(1): 1-10. [doi:10.1111/1574-6968.12348]

Murakami, A., 2014. Dose-dependent functionality and toxicity of green tea polyphenols in experimental rodents. Arch. Biochem. Biophys., 557:3-10. [doi:10.1016/j.abb.2014.04. $018]$

NRC (National Research Council), 1994. Nutrient Requirements of Poultry. National Academy Press, Washington, DC.

Park, J.E., Oh, S.H., Cha, Y.S., 2014. Lactobacillus brevis OPK-3 isolated from kimchi inhibits adipogenesis and exerts anti-inflammation in 3T3-L1 adipocyte. J. Sci. Food Agric., 94(12):2514-2520. [doi:10.1002/jsfa.6588]

Postal, M., Appenzeller, S., 2015. The importance of cytokines and autoantibodies in depression. Autoimmun. Rev., 14(1):30-35. [doi:10.1016/j.autrev.2014.09.001]

Qin, B.L., Polansky, M.M., Harry, D., et al., 2010. Green tea polyphenols improve cardiac muscle mRNA and protein 
levels of signal pathways related to insulin and lipid metabolism and inflammation in insulin-resistant rats. Mol. Nutr. Food Res., 54(S1):S14-S23. [doi:10.1002/ mnfr.200900306]

Rashti, Z., Koohsari, H., 2015. Antibacterial effects of supernatant of lactic acid bacteria isolated from different Dough's in Gorgan city in north of Iran. Integr. Food Nutr. Metab., 2(3):193-196. [doi:10.15761/IFNM.1000129]

Shen, C.L., Samathanam, C., Tatum, O.L., et al., 2011a. Green tea polyphenols avert chronic inflammation-induced myocardial fibrosis of female rats. Inflamm. Res., 60(7): 665-672. [doi:10.1007/s00011-011-0320-y]

Shen, C.L., Yeh, J.K., Samathanam, C., et al., 2011 b. Protective actions of green tea polyphenols and alfacalcidol on bone microstructure in female rats with chronic inflammation. J. Nutr. Biochem., 22(7):673-680. [doi:10.1016/j.jnutbio.2010.05.007]

Singh, M., Singh, R., Bhui, K., et al., 2011. Tea polyphenols induce apoptosis through mitochondrial pathway and by inhibiting nuclear factor- $\mathrm{\kappa B}$ and Akt activation in human cervical cancer cells. Oncol. Res., 19(6):245-257. [doi:10. 3727/096504011X13021877989711]

Wu, L., Wang, W., Yao, K., et al., 2013. Effects of dietary arginine and glutamine on alleviating the impairment induced by deoxynivalenol stress and immune relevant cytokines in growing pigs. PLOS ONE, 8(7):e69502. [doi:10.1371/journal.pone.0069052]

Yang, F., Hou, C., Zeng, X., et al., 2015. The use of lactic acid bacteria as a probiotic in Swine diets. Pathogens, 4(1): 34-45. [doi:10.3390/pathogens4010034]

Yin, J., Ren, W., Liu, G., et al., 2013a. Birth oxidative stress and the development of an antioxidant system in newborn piglets. Free Radic. Res., 47(12):1027-1035. [doi:10. 3109/10715762.2013.848277]

Yin, J., Ren, W.K., Wu, X.S., et al., 2013b. Oxidative stressmediated signaling pathways: a review. J. Food Agric. Environ., 11(2):132-139.

Yin, J., Wu, M.M., Xiao, H., et al., 2014a. Development of an antioxidant system after early weaning in piglets. J. Anim. Sci., 92(2):612-619. [doi:10.2527/jas.2013-6986]

Yin, J., Ren, W., Duan, J., et al., 2014b. Dietary arginine supplementation enhances intestinal expression of SLC7A7 and SLC7A1 and ameliorates growth depression in mycotoxin-challenged pigs. Amino Acids, 46(4):883-892. [doi:10.1007/s00726-013-1643-5]

Yin, J., Liu, M., Ren, W., et al., 2015a. Effects of dietary supplementation with glutamate and aspartate on diquatinduced oxidative stress in piglets. PLOS ONE, 10(4): e0122893. [doi:10.1371/journal.pone.0122893]

Yin, J., Duan, J., Cui, Z., et al., 2015b. Hydrogen peroxideinduced oxidative stress activates NF- $\kappa \mathrm{B}$ and Nrf2/Keap1 signals and triggers autophagy in piglets. RSC $A d v$., 5(20):15479-15486. [doi:10.1039/C4RA13557A]

Zhong, L., Zhang, X.F., Covasa, M., 2014. Emerging roles of lactic acid bacteria in protection against colorectal cancer. World J. Gastroenterol., 20(24):7878-7886. [doi:10.3748/ wjg.v20.i24.7878]

\section{中文摘要}

题 目: 茶多酚和乳酸菌影响肉鸡血液生化、消化酶以及 肠道细胞因子表达的研究

目 的: 茶多酚和乳酸菌在动物营养上的作用已经得到广 泛的验证, 但是关于二者联合作用的研究鲜有报 道。本文采用肉鸡作为试验模型, 研究了茶多酚 和乳酸菌联合灌喂对肉鸡血液生化、消化酶以及 肠道细胞因子表达的影响。

创新点: 本研究首次采用联合灌喂茶多酚和乳酸菌, 探讨 了二者联合作用对肉鸡的影响, 并通过模拟生产, 长期观察了茶多酚和乳酸菌对肉鸡的影响。

方 法: 对肉仔鸡灌喂不同浓度的茶多酚和乳酸菌, 在第 56 和 84 天随机屠宰取样。收集血液检查血液生 化指标, 并测定消化酶活性。取肠道样品提取 RNA，采用反转录聚合酶链反应（RT-PCR）检 测细胞因子的表达以及相关信号通路的激活。

结 论: 长期灌喂茶多酚和乳酸菌改善了肉鸡脂质代谢、 消化酶活性以及炎症反应, 其机制可能是通过影 响了 NF- $\mathrm{NB}$ 信号通路。

关键词: 茶多酚; 乳酸菌; NF- $\mathrm{kB}$; 肉鸡 